\title{
Sugarcane Productivity Simulation Under Different Scenarios by DSSAT/CANEGRO Model in the Western São Paulo
}

\author{
Angela Madalena Marchizelli Godinho ${ }^{1}$, Asdrubal Jesus Farias-Ramírez ${ }^{2}$, Maria Alejandra Moreno-Pizani ${ }^{2}$, \\ Tadeu Alcides Marques ${ }^{3}$, Franklin Javier Paredes-Trejo ${ }^{4} \&$ Carlos Sérgio Tiritan ${ }^{1}$ \\ ${ }^{1}$ Agronomy Doctoral Program, University of Western São Paulo, Presidente Prudente São Paulo, Brazil \\ ${ }^{2}$ Faculdade PECEGE, Piracicaba, São Paulo, Brazil \\ ${ }^{3}$ College of Technology of Piracicaba "Deputy Roque Trevisan" (FATEC-Piracicaba) CEETPS, State Center of \\ Technological Education, Piracicaba, São Paulo, Brazil \\ ${ }^{4}$ Department of Civil Engineering, University of the Western Plains Ezequiel Zamora, San Carlos, Cojedes, \\ Venezuela \\ Correspondence: Maria Alejandra Moreno-Pizani, Faculdade Pecege. R. Alexandre Herculano, 120-Vila \\ Monteiro, Piracicaba, São Paulo, 13418-445, Brazil. Tel: 55-19-3377-0937. E-mail: morenom76@gmail.com
}

Received: April 30, 2020

Accepted: May 31, $2020 \quad$ Online Published: June 15, 2020

doi:10.5539/jas.v12n7p82

URL: https://doi.org/10.5539/jas.v12n7p82

\begin{abstract}
Sugarcane (Saccharum officinarum L.) is one of the most important crops in Brazil and its growth and development can be simulated through process-based models. The current study evaluated a model based on the decision support system for the transfer of Agrotechnology DSSAT/CANEGRO to simulate the sugarcane crop productivity in the western region of São Paulo. The DSSAT/CANEGRO model was calibrated using published yield parameters from a selection of five Brazilian sugarcane cultivars, while sugarcane yield data (tons of stems per hectare) from commercial land were used as benchmark data. Other modeling inputs were derived from the primary regional cultivar. The root mean square error (RMSE), Willmott agreement index (d), and mean absolute error (MAE) were used as performance metrics. The DSSAT/CANEGRO model resulted in a good RMSE performance. The productivity estimates were better for the cultivars SP791010 and RB835486, with RMSE equal to 2.27 and $4.48 \mathrm{Mg} \mathrm{ha}^{-1}$, respectively. The comparison between model-based estimates and observed data produced d values in the range from 0.86 to 0.99 , and MAE values in the range of 1.84 to $4.22 \mathrm{Mg} \mathrm{ha}^{-1}$.
\end{abstract}

Keywords: Saccharum officinarum, yield forecast, modeling

\section{Introduction}

The cultivation of sugarcane (Saccharum officinarum) is among the most important crops in Brazilian agribusiness. Brazil is the world's largest sugarcane producer and the second largest producer of ethanol. The areas under production continue to gradually increase, although at a slower pace in the midwest states in Brazil and southeast regions. Since 2008, industrial units of sugarcane processing facilities were installed in the west of São Paulo state, which facilitated developing additional sugarcane fields (CONAB, 2018). This region has some edaphoclimatic characteristics that are different from the other sugarcane regions of the state, such as sandy soils with low water retention capacity, high temperatures, heavy rains and long periods without rain (summer), which promote plant water stress.

There are different models for estimating growth and evaluating the development of process-based cultures that can facilitate monitoring and contribute to activities related to productivity forecasting, as well as assist in understanding those mechanisms that are directly involved in the different responses of culture to the environmental conditions (Marin et al., 2011; Nassif et al., 2012).

According to Marin et al. (2011), currently there are several models that can be used for sugarcane growth simulations, such as: AUSCANE (Jones et al., 1988), QCANE (Liu \& Kingston, 1995), APSIM (Keating et al., 1999), and CASUPRO (Villegas et al., 2005). One of the main and most used models is the DSSAT/CANEGRO (Inman-Bamber, 1991; Singels \& Bezuidenhout, 2002) is also one of the main simulation models of growth of the sugarcane currently in use (Nassif et al., 2012). The DSSAT/CANEGRO model is based on the Ceres-Maize 
model (Jones et al., 1986), which was developed to model the most important physiological processes related to sugar production processes in South Africa (Inman-Bamber, 1991).

The DSSAT/CANEGRO model is being used in different regions of the world to analyze the different sugarcane production systems (Inman-Bamber, 1991; Marin et al., 2011; Singels \& Bezuidenhout, 2002; Singels et al., 2008; Nassif et al., 2012). In Brazil, Marin et al. (2011) calibrated the DSSAT/CANEGRO model for two cultivars in the production systems of the center-south of Brazil.

Thus, the aim of this study is to estimate the sugarcane productivity under conditions in the western portion of the state of São Paulo. The following specific objectives will be developed: (i) to evaluate the DSSAT model under different climatic and soil conditions for sugarcane production; (ii) to evaluate the performance of the DSSAT model using data reported by the sugarcane mills, and (iii) to evaluate the sugarcane productivity estimates in the western portion of the state of São Paulo, Brazil.

\section{Method}

\subsection{Model Description}

Sugarcane productivity simulations in western portion of São Paulo state were carried out with the DSSAT/CANEGRO version 4.5 to model the most relevant sugarcane physiological processes, whereas the Weatherman subroutine to analyze the climatic data.

The DSSAT/CANEGRO model requires water balance information and daily meteorological data (i.e., solar radiation, maximum and minimum temperatures, and precipitation). The sugarcane growth modeling includes phenology, canopy development, accumulation of biomass and sucrose, partitioning, root growth, water stress and lodging data (Singels et al., 2008). The model also requires soil physics data (i.e., field capacity, permanent wilting point, water saturation and soil depth) at the entrance of the process to adjust the water balance (Nassif et al., 2012).

\subsection{Input Variables by the Simulations}

The input variables were: precipitation $(\mathrm{P})(\mathrm{mm})$, air temperature (Tmax) (Tmin) (Tmed) (maximum, minimum and average) $\left({ }^{\circ} \mathrm{C}\right)$, solar radiation (Rs) $\left(\mathrm{MJ} \mathrm{m}^{-2}\right)$, average relative humidity $(\mathrm{RH})(\%)$ and average wind speed (m $\mathrm{s}^{-1}$ ) provided by the National Institute of Meteorology (INMET, http://www.inmet.gov.br) on a daily basis. The soil physical-chemical characteristics used to describe the soil's water storage capacity were: the permanent wilting point $\left(\mathrm{cm}^{3} \mathrm{~cm}^{-3}\right)$, field capacity $\left(\mathrm{cm}^{3} \mathrm{~cm}^{-3}\right)$, saturation point $\left(\mathrm{cm}^{3} \mathrm{~cm}^{-3}\right)$, cation exchange capacity ( $\mathrm{cmol}$ $\left.\mathrm{kg}^{-1}\right)$ and soil organic matter $\left(\mathrm{g} \mathrm{kg}^{-1}\right)$.

The varieties used to perform the simulations (RB835486, SP791011, RB931530, and RB93509) were selected based on the sugar mill productivity data for the last 15 years. The RB867515 cultivar parameters were used to calibrate the model. These cultivars were selected due to their representativeness in planting sugarcane fields in the studied region.

The soil profile characterizations were classified according to the Pedological Map of São Paulo state presented by Rossi (2017). The most representative soils of the Presidente Prudente-SP microregion were used in the simulation: Argilossos and Latossolos according to Brazilian System of Soil Classification (SiBCS) (Santos et al., 2013), which are equivalent to Ultisols and Typic Hapludox subgroups, respectively, according to U.S. Soil Taxonomy (Soil Survey Staff, 2019).

\subsection{Method of Acquisition, Selection and Transformation of Climatic Data}

The metadata used for weather stations are shown in Table 1. The region of western São Paulo state on the borders with Paraná and Mato Grosso do Sul state, has a tropical climate, type CWa according to the Köppen climate classification, characterized by hot and rainy summers, and cold and dry winters. The average annual precipitation is $1,308 \mathrm{~mm}$, with a maximum of $2,049 \mathrm{~mm}$ in 2009. January has the highest average rainfall (212 $\mathrm{mm}$ ), according to data recorded by the meteorological station of Presidente Prudente from 1969 to 2013. Severe drought events were observed, demonstrating again the great randomness and complexity of the atmospheric system, with the year 2001 being classified as unusual with relation to climate normals. La Niña's (a cold phase oscillation quasiperiodic of climate pattern that arises across the tropical Pacific Ocean on the coast of Peru and Ecuador every five years) (Gómez-Aguilar, 2020) years are no exception to this characteristic, even though they tend to be drier years. El Niño (describe the warm oceanic phase of climate pattern) (Gómez-Aguilar, 2020) years are characterized in most cases by the presence of extreme events in the region, such as intense rains (Berezuk \& Neto, 2006) (Figure 2b). 
Table 1. Weather stations in the region of Presidente Prudente, SP

\begin{tabular}{llllll}
\hline Station & State & Code & Latitude & Longitude & Elevation $(\mathrm{m})$ \\
\hline Ivinhema & MS & 83704 & $-22.3^{\circ}$ & $-53.81^{\circ}$ & 369.00 \\
Londrina & PR & 83766 & $-23.3^{\circ}$ & $-51.13^{\circ}$ & 566.00 \\
Maringa & PR & 83767 & $-23.4^{\circ}$ & $-51.91^{\circ}$ & 542.00 \\
Presidente Prudente & SP & 86863 & $-22.1^{\circ}$ & $-51.40^{\circ}$ & 435.55 \\
\hline
\end{tabular}

Note. *MS: Mato Grosso do Sul PR: Paraná SP: São Paulo.

The analyzes were performed with production data provided by the industry (sugarcane yield observed), located in Dracena 22 $07^{\prime} 51.3^{\prime \prime}$ S; 51 ${ }^{\circ} 24^{\prime} 9.6^{\prime \prime}$ W, 436 m elevation, in the west of state of São Paulo, Brazil. The relative location of meteorological stations in the region of Presidente Prudente, São Paulo, Brazil are shown in Figure 1.

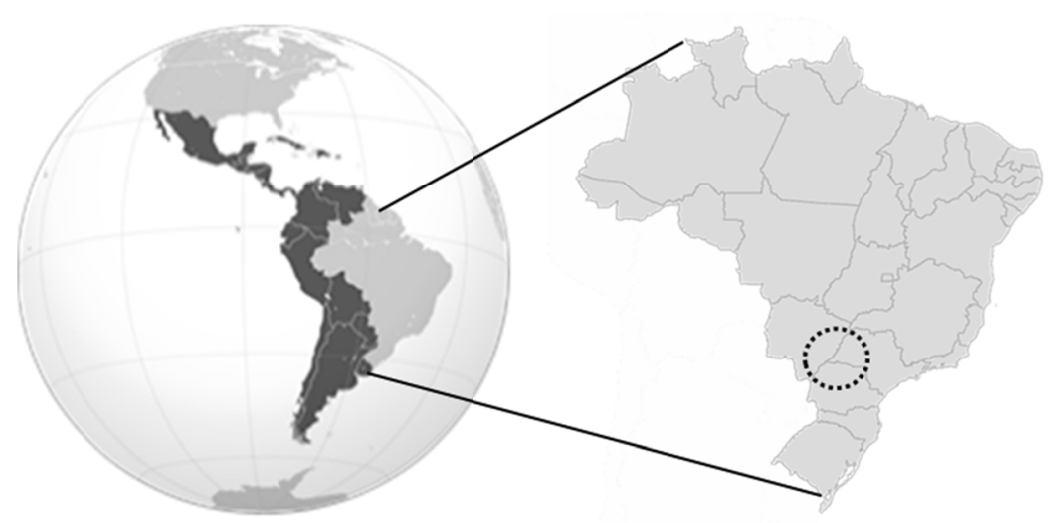

Figure 1. Relative location of the selected INMET meteorological stations

\subsubsection{Determination of the Water Demands of Eugarcane (ETo)}

To determine the reference evapotranspiration (ETo), the climatological data published by the National Institute of Meteorology (INMET, http://www.inmet.gov.br) were used. The calculation of ETo was performed using the Penman-Monteith method (Allen et al., 1998; Raes et al., 2012), as recommended by Jensen et al. (1990) according to Equation 1.

$$
\begin{gathered}
\mathrm{ET}_{\mathrm{o}}=\frac{0.408 \cdot \mathrm{s} \cdot\left(\mathrm{R}_{\mathrm{n}}-\mathrm{G}\right)+\gamma \cdot 900 \cdot \mathrm{U}_{2}\left[\frac{\left.\mathrm{e}_{\mathrm{s}}-\mathrm{e}_{\mathrm{a}}\right]}{\mathrm{T}+\gamma \cdot\left(1+0.34 \cdot \mathrm{U}_{2}\right)}\right.}{\mathrm{s}=0.38 \cdot\left(\mathrm{T}_{\mathrm{d}}-\mathrm{T}_{3 \mathrm{~d}}\right)} \\
\mathrm{e}_{\mathrm{s}}=\frac{0.6108 \cdot \mathrm{e}\left[\left(17.27 T_{\max }\right) /\left(237.7+\mathrm{T}_{\max }\right)\right]+0.6108 \cdot \mathrm{e}\left[\left(17.27 \mathrm{~T}_{\min }\right) /\left(237.7+\mathrm{T}_{\min }\right)\right]}{2} \\
\mathrm{e}_{\mathrm{a}}=\frac{\left(\mathrm{UR} \cdot \mathrm{e}_{\mathrm{s}}\right)}{100} \\
\mathrm{e}_{\mathrm{a}}=\frac{4098 \cdot \mathrm{e}_{\mathrm{s}}}{(\mathrm{T}+237.3)^{2}}
\end{gathered}
$$

Where, ETo: reference evapotranspiration $\left(\mathrm{mm} \mathrm{day}^{-1}\right)$; Rn: total daily net radiation $\left(\mathrm{MJ} \mathrm{m}^{-2}\right.$ day $\left.^{-1}\right)$; G: soil heat flux density $\left(\mathrm{MJ} \mathrm{m}^{-2}\right.$ day $\left.^{-1}\right) ; \gamma$ : psychometric constant $\left(0.063 \mathrm{kPa}^{\circ} \mathrm{C}^{-1}\right)$; Td: average daily temperature $\left({ }^{\circ} \mathrm{C}\right) ; \mathrm{U}_{2}$ : wind speed at $2 \mathrm{~m}$ height $\left(\mathrm{m} \mathrm{s}^{-1}\right)$; $\mathrm{e}_{\mathrm{s}}$ : saturation vapor pressure $(\mathrm{kPa})$; $\mathrm{e}_{\mathrm{a}}$ : actual vapor pressure $(\mathrm{kPa})$; s: rate of change of vapor pressure in relation to temperature $\left(\mathrm{kPa}^{\circ} \mathrm{C}^{-1}\right)$.

The description of the parameters of the cultivars and their units are based on work of Nassif et al. (2012) and Marin et al. (2015), as shown in Table 2. 
Table 2. Description of the cultivar parameters and units needed to run the simulation in the DSSAT/CANEGRO model with the sugarcane cultivars representative of the western São Paulo.

\begin{tabular}{|c|c|c|}
\hline Parameter & Unit & Description \\
\hline Parcemáx & $\mathrm{g} \mathrm{MJ}^{-1}$ & $\begin{array}{l}\text { Maximum (no stress) radiation conversion efficiency expressed as assimilate produced before respiration per } \\
\text { unit of photosynthetic active radiation (PAR) }\end{array}$ \\
\hline APFMX & $\mathrm{Mg} \mathrm{Mg}^{-1}$ & Maximum fraction of dry mass increments that can be allocated to aerial dry mass \\
\hline STKPFmáx & $\mathrm{Mg} \mathrm{Mg}^{-1}$ & Fraction of daily aerial dry mass increments partitioned to stalk at high temperatures in a mature crop \\
\hline Suca & $\mathrm{Mg} \mathrm{Mg}^{-1}$ & Maximum sucrose contents in the base of stalk \\
\hline TBFT & ${ }^{\circ} \mathrm{C}$ & Temperature at which partitioning of unstressed stalk mass increments to sucrose is $50 \%$ of the maximum value \\
\hline Tthalfo & ${ }^{\circ} \mathrm{C} d$ & Thermal time to half canopy \\
\hline Tbase & ${ }^{\circ} \mathrm{C}$ & Base temperature for canopy development \\
\hline LFmáx & Leaves & $\begin{array}{l}\text { Maximum number of green leaves a healthy, adequately irrigated plant will have after it is old enough to lose } \\
\text { some leaves }\end{array}$ \\
\hline MXLFArea & $\mathrm{cm}^{2}$ & Max leaf area assigned to all leaves above leaf number MXLFARNO \\
\hline MXLFArno & Leaves & Leaf number above which leaf area is limited to MXLFAREA \\
\hline P11 & ${ }^{\circ} \mathrm{C} \mathrm{d}$ & Phyllocron interval 1 (for leaf numbers below PSWITCH) \\
\hline $\mathrm{P} 12$ & ${ }^{\circ} \mathrm{C} \mathrm{d}$ & Phyllocron interval 2 (for leaf numbers above PSWITCH) \\
\hline Pswitch & Leaves & Leaf number at which the phyllocron changes \\
\hline TTPLNTEM & ${ }^{\circ} \mathrm{C} \mathrm{d}$ & Degree-days to emergence for a plant crop \\
\hline TTRATNEM & ${ }^{\circ} \mathrm{C} d$ & Degree-days to emergence for a ratoon crop \\
\hline ChupiBase & ${ }^{\circ} \mathrm{C} \mathrm{d}$ & Degree-days from emergence to start of stalk growth \\
\hline TT_PopGrowth & ${ }^{\circ} \mathrm{C} \mathrm{d}$ & Degree-days from emergence to peak tiller population \\
\hline Max_Pop & $\mathrm{Mg} \mathrm{m}^{-2}$ & Maximum tillers population \\
\hline PopTT16 & $\mathrm{Mg} \mathrm{m}^{-2}$ & $\mathrm{Mg}$ population after 1.600 degree-days \\
\hline LG_AMBase & $\mathrm{Mg} \mathrm{ha}^{-1}$ & Aerial or fresh mass (stalks, leaves and water attached to them) where lodging starts \\
\hline
\end{tabular}

Source: Singels et al., 2008; Nassif et al., 2012; Marin et al., 2015.

The RB867515 cultivar was previously calibrated for the DSSAT/Canegro and APSIM/Sugar models using inputs from six different regions of Brazil (Marin et al., 2013). The values of the parameters of each cultivar used in the simulation for the DSSAT/CANEGRO model are summarized in Table 3.

Table 3. Values of the cultivar parameters used in the simulation for the DSSAT/CANEGRO model.

\begin{tabular}{llllllll}
\hline Parameter & RB867515 & RB835486 & RB92579* & RB92579 & SP791011 & RB931530 & RB93509 \\
\hline Parcemáx & 12.860 & 13.520 & 10.8 & 13.5 & 7.7 & 6.5 & 9.86 \\
APFMX & 0.843 & 0.865 & 0.92 & 0.9 & 0.88 & 0.9 & 0.8 \\
STKPFmáx & 0.699 & 0.760 & 0.88 & 0.88 & 0.55 & 0.55 & 0.69 \\
Suca & 0.680 & 0.695 & 0.57 & 0.57 & 0.58 & 0.58 & 0.68 \\
TBFT & 25 & 26 & 25 & 25 & 25 & 25 & 25 \\
Tthalfo & 250.800 & 257.800 & 286 & 230 & 250 & 250 & 250.8 \\
Tbase & 15.710 & 15.620 & 14 & 14 & 15 & 14 & 15.71 \\
LFmáx & 9.960 & 9.518 & 8 & 8 & 12 & 12 & 9 \\
MXLFArea & 500.200 & 500.900 & 792 & 680 & 380 & 680 & 435 \\
MXLFArno & 17.190 & 15.350 & 22 & 14 & 14 & 14 & 14 \\
P11 & 89.000 & 90.100 & 109 & 65 & 90 & 90 & 110 \\
P12 & 150.000 & 149.400 & 117 & 179 & 179 & 179 & 200 \\
Pswitch & 16.140 & 16.330 & 22 & 18 & 18 & 18 & 14 \\
TTPLNTEM & 300.400 & 509.400 & 428 & 615 & 628 & 628 & 628 \\
TTRATNEM & 290.900 & 211.400 & 620 & 203 & 203 & 203 & 290 \\
ChupiBase & 855.000 & 547.600 & 1050 & 533 & 1050 & 1050 & 855 \\
TT_PopGrowth & 650.400 & 530.200 & 628 & 789 & 700 & 700 & 800 \\
Max_Pop & 20.350 & 19.620 & 28 & 28 & 15 & 16 & 19.7 \\
PopTT16 & 8.190 & 9.556 & 12 & 11 & 9.2 & 7.8 & 8.3 \\
LG_AMBase & 220 & 220 & 220 & 220 & 200 & 200 & 220 \\
\hline
\end{tabular}

Note. * Standard cultivar used for comparison purposes; ** Varieties parameterized by (Barros et al., 2016).

Source: Nassif et al., 2012. 


\subsubsection{Simulation Scenarios}

The scenarios were based on the maturation cycle of the cultivars used: early, medium and late; three harvest seasons June 15th (early), August 15th (medium) and September 15th (late). Ten years of planting were simulated for each combination of climate and soil. Thus, for each location, the five varieties and two soils were considered, totaling 10 scenarios per region (Table 4). The planting date in all cases was on the 15 th of June.

Table 4. List of items used to compose the simulation scenarios to evaluate the DSSAT/CANEGRO model

\begin{tabular}{|c|c|c|c|c|c|c|}
\hline Weather Station & Soil & Cultivar & Maturity & Production System & Planting Depth $(\mathrm{cm})$ & Harvest Date \\
\hline Ivinhema & \multirow{4}{*}{$\begin{array}{l}\text { Latossolo } \\
\text { (Typic Hapludox)* } \\
\text { Argissolo (Ultisols)* }\end{array}$} & RB931530; RB835486 & Early & \multirow{4}{*}{ Rainfed } & \multirow{4}{*}{20} & 15/Jun \\
\hline Londrina & & RB867515 & Average & & & \multirow{2}{*}{ 15/Aug } \\
\hline Maringa & & SP791011 & & & & \\
\hline Presidente Prudente & & RB93509 & Late & & & $15 / \mathrm{Sep}$ \\
\hline
\end{tabular}

Note. * Soil classification according to the Brazilian System of Soil Classification (SiBCS) (Santos et al., 2013) and its equivalent according to the closest Soil Survey Staff (2019) (in parentheses).

\subsubsection{Evaluation of Performance of the Models}

In this study, the agreement index (d), mean error (ME), mean absolute error (MAE), and root mean square error (RMSE) were used as performance statistical metrics (Willmott et al., 1985), with Equations (6 to 9) as follows:

$$
\begin{gathered}
\mathrm{d}=1-\left[\frac{\sum_{\mathrm{i}=1}^{\mathrm{n}}\left(\mathrm{Y}_{\mathrm{i}}-\mathrm{Y}\right)^{2}}{\sum_{\mathrm{i}=1}^{\mathrm{n}}\left(\left|\mathrm{Y}_{\mathrm{i}}-\mathrm{Y}_{\mathrm{m}}\right|+\mid \mathrm{Y}-\mathrm{Y}_{\mathrm{m}}\right)^{2}}\right] \\
\mathrm{ME}=\frac{\sum_{\mathrm{i}=1}^{\mathrm{n}}\left(\mathrm{Y}_{\mathrm{i}}-\mathrm{Y}\right)}{\mathrm{n}} \\
\mathrm{MAE}=\frac{\sum_{\mathrm{i}=1}^{\mathrm{n}}\left(\left|\mathrm{Y}_{\mathrm{i}}-\mathrm{Y}\right|\right)}{\mathrm{n}} \\
\mathrm{RMSE}=\sqrt{\frac{\sum_{\mathrm{i}=1}^{\mathrm{n}}\left(\mathrm{Y}_{\mathrm{i}}-\mathrm{Y}\right)^{2}}{\mathrm{n}}}
\end{gathered}
$$

Where, Yi and $\mathrm{Y}$ are the estimated and observed sugarcane yield, in $\mathrm{Mg} \mathrm{ha}^{-1}$, respectively; $\mathrm{Ym}$ are the average of estimated and observed sugarcane yield, in $\mathrm{Mg} \mathrm{ha}^{-1}$; and $\mathrm{n}$ is the number of observations.

\section{Results and Discusions}

\subsection{Meteorological Conditions}

Weather conditions during sugarcane period scenarios from January 1969 to December 2013 are shown in Figure 2a. The values of, ETo was lower than precipitation (P), with ETo equal to $200 \mathrm{~mm}$ in the summer humid season and $25 \mathrm{~mm}$ in winter (Figure $2 \mathrm{~b}$ ). 


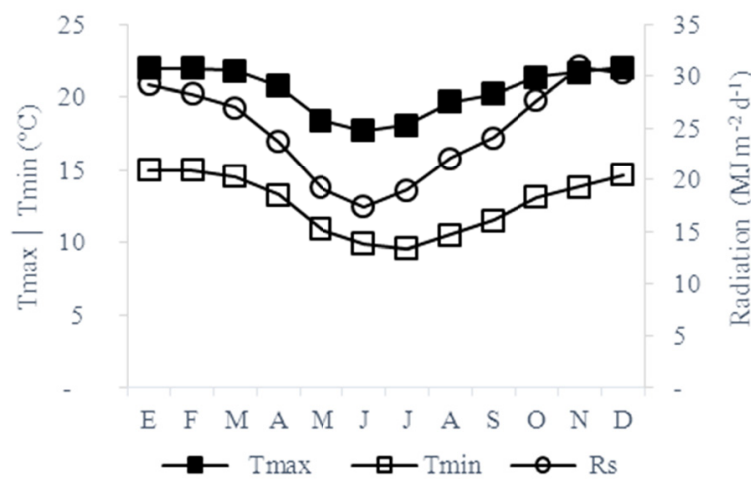

(a)

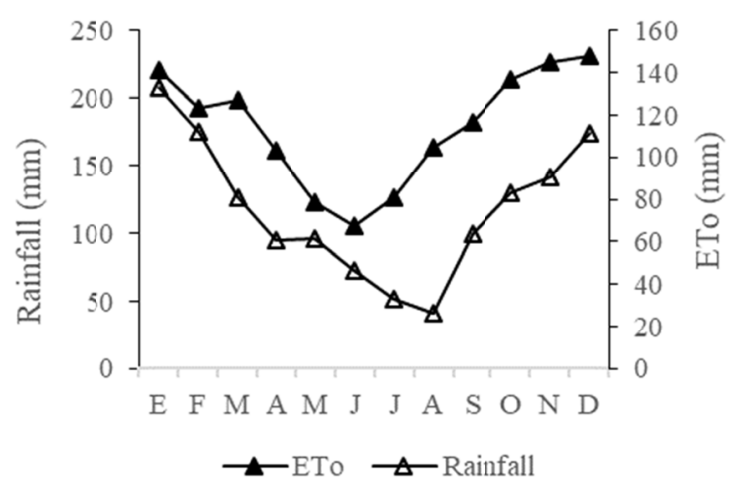

(b)

Figure 2. Maximum monthly average (Tmax) and (Tmin) air temperature and incident solar radiation (a), and daily precipitation and reference evapotranspiration (ETo) calculated in the region of Presidente Prudente - SP, based on data from selected stations (b)

Outcomes from the DSSAT/CANEGRO model show that the RB98509 cultivar in the Ultisols soil type presented the highest productivity in the period 2009. The RB867515 cultivar showed high productivity throughout the periods of evaluation. Finally, the cultivars RB93509, RB931530, and RB835486 presented in all scenarios resulted in the lowest productivity in terms of Mg per hectare (Figure 3a). Figure 3b shows the average productivity of $\mathrm{Mg} \mathrm{ha}{ }^{-1}$ for all cultivars, with data from Londrina Station, in the Ultisols and Typic Hapludox soils, for the region of Oeste Paulista - SP, (10 yr average).

The cultivar RB98509 with the soil type Ultisols produced the highest productivity (above $120 \mathrm{Mg} \mathrm{ha}^{-1}$ ) in 2009. Similarly, this same variety performed best $\left(\mathrm{Mg} \mathrm{ha}^{-1}\right)$ in the Typic Hapludox soil in the same year. In the case of Ultisols, only achieved $110 \mathrm{Mg} \mathrm{ha}^{-1}$. On the other hand, the RB867515 showed high productivity in all soil types during all the evaluation periods. The varieties RB93509, RB931530, and RB835486 resulted in the lowest yields in all scenarios with average yields between 40 and $70 \mathrm{Mg} \mathrm{ha}^{-1}$.

The average yields for RB835486, RB867515, RB931530, RB93509 and SP791011, are shown in Figure 3 when grown on Ultisols and Typic Hapludox soils during a 10-year period (2003-2013) at the Maringá Station in the western- SP region. Note that the variety RB98509 in the Ultisol soils in 2009 produced the greatest yields, over $130 \mathrm{Mg} \mathrm{ha}^{-1}$. Similarly, this same variety produced high yields on the Typic Hapludox soil in the same year. In the case of Ultisols, just exceeded $110 \mathrm{Mg} \mathrm{ha}^{-1}$. The behavior of the RB867515 variety, was characterized by high productivity in the soil types during all the evaluation periods.

Finally, in each scenario the varieties RB93509, RB931530, and RB835486 produced the lowest yields, averaging between 55 and $85 \mathrm{Mg} \mathrm{ha}^{-1}$ (Figure 3c). Interestingly, RB98509 in 2004 on the Ultisols produced the highest yields with values close to $140 \mathrm{Mg} \mathrm{ha}^{-1}$. The RB867515 variety with an average maturation showed high productivity above $120 \mathrm{Mg} \mathrm{ha}^{-1}$ in all the soil during all the evaluation periods. Finally, the varieties RB93509, RB931530, and RB835486 resulted in the lowest yield in all scenarios evaluated with average yield values between 60 and $85 \mathrm{Mg} \mathrm{ha}^{-1}$ (Figure 3d). 
(a)
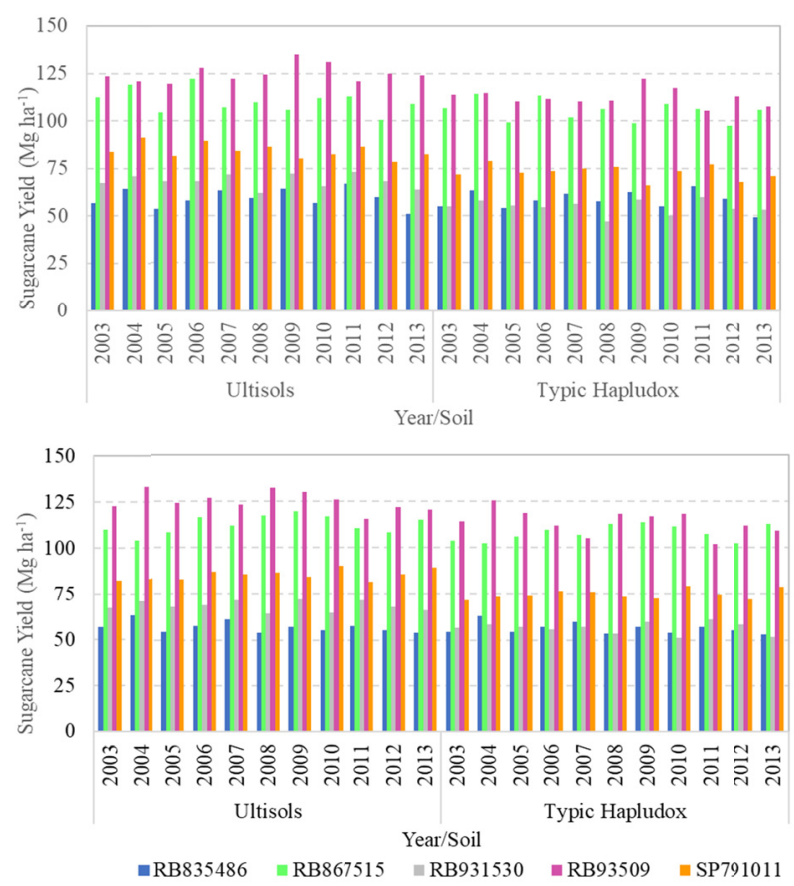

(c) (b)
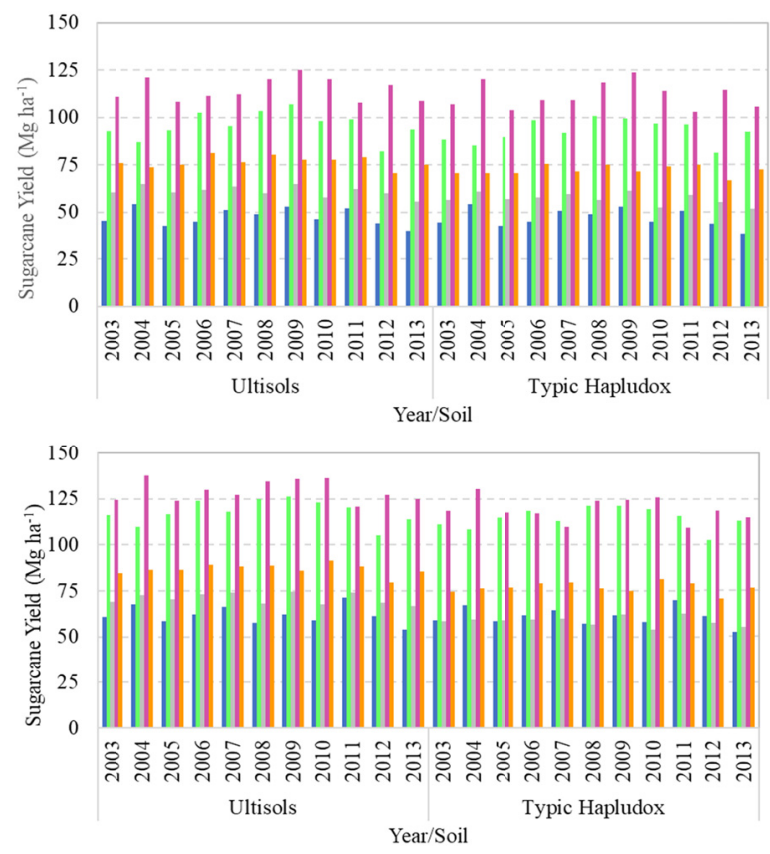

(d)

Figure 3. Productivity in $\mathrm{Mg} \mathrm{ha}^{-1}$, for varieties RB835486, RB867515, RB931530, RB93509 and SP791011, with data from Ivinhema Station (a), Londrina (b) Maringá (c) and Presidente Prudente (d), in the Ultisols and Latossolo soils, for the region of Oeste Paulista-SP and the validation period (10 years)

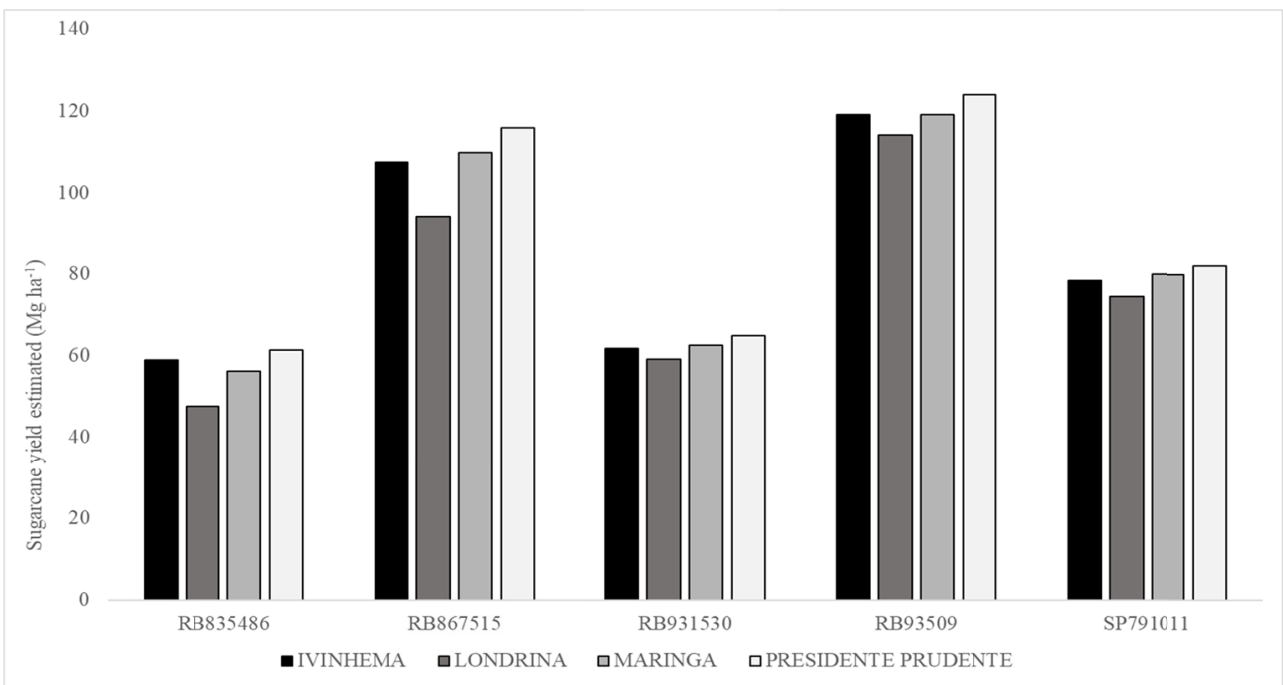

Figure 4. The sugarcane yield averages estimated expressed in $\mathrm{Mg} \mathrm{ha}^{-1}$ for the varieties RB835486, RB867515, RB931530, RB93509 and SP791011, with data from Ivinhema, Londrina, Presidente stations Prudente, Maringá in the Ultisols and Typic Hapludox soils, for the region, over a 10-year period. Note that in all locations the variety RB93509 was the one with the highest productivity, with $118 \mathrm{Mg} \mathrm{ha}^{-1}$, whereas the opposite is observed for the variety $\mathrm{RB} 835486$ with values close to $60 \mathrm{Mg} \mathrm{ha}^{-1}$

The relationship between the estimated productivity and the sugarcane yield observed in $\mathrm{Mg}^{-1}$ is shown in Figure 5. In terms of observed productivity for the RB835486 variety, the simulated values underestimated the registered data by the industry. 
The simulation results for RB867515 exceeded the productivity data provided by the industry. Regarding the SP791011 variety, the simulation was closer to the observed data provide by the industry. The varieties RB92579 and RB931530 were disregarded in this analysis due to the absence of productivity records during the evaluated period.

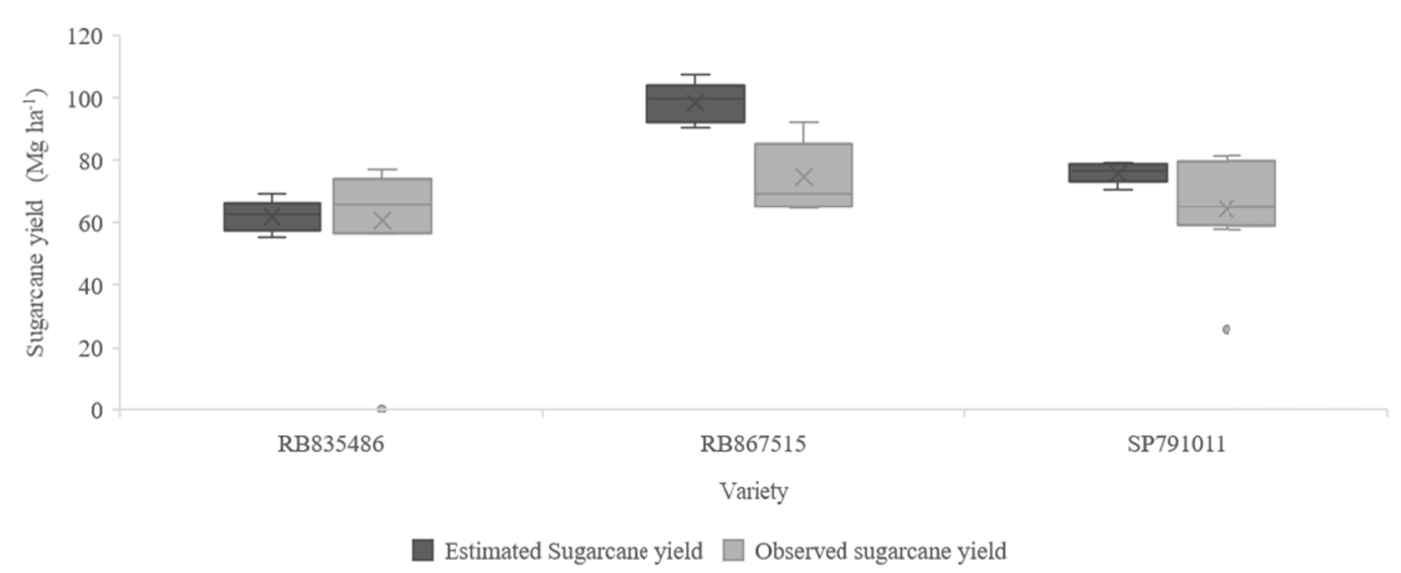

Figure 5. Relationship between estimated sugarcane yield and observed sugarcane yield at the evaluated locations

\subsection{Performance of the Models}

The performance indicators for the evaluated locations are shown in Table 5. In terms of precision and accuracy, it was found that the estimates are consistent with the results of some previous studies in Brazil (Marin et al., 2015, 2013; Nassif et al., 2012; Marin et al., 2011; Nassif et al., 2012; Dos Santos \& Sentelhas, 2016). Note, however, that the RMSA values were lower or similar to those reported by these authors. For example, Singels et al. (2010) obtained RMSE $=29.8 \mathrm{Mg} \mathrm{ha}^{-1}$ from simulations with DSSAT/CANEGRO considering several cultivars considering in Piracicaba, SP.

The RMSE values found in this study were also lower or similar to those obtained with DSSAT/CANEGRO for different cultivars in South Africa, Australia, Zimbabwe and Thailand by Singels et al. (2008).

Table 5. Performance statistical metrics in the evaluated locations

\begin{tabular}{lllll}
\hline Cultivar & $\mathrm{d}[$ dimensionless $]$ & $\mathrm{ME}\left[\mathrm{Mg} \mathrm{ha}^{-1}\right]$ & $\mathrm{ME}\left[\mathrm{Mg} \mathrm{ha}^{-1}\right]$ & $\mathrm{RMSE}\left[\mathrm{Mg} \mathrm{ha}{ }^{-1}\right]$ \\
\hline RB835486 & 0.86 & $3.16 \mathrm{E}^{-15}$ & 3.85 & 4.48 \\
RB867515 & 0.98 & $-6.09 \mathrm{E}^{-15}$ & 4.22 & 4.93 \\
SP791011 & 0.99 & 0.00 & 1.84 & 2.27 \\
\hline
\end{tabular}

\section{Conclusion}

The DSSAT model allowed the simulation of sugarcane productivity in the region of western São Paulo state to establish comparisons with the data observed by the industry, making it possible to evaluate the behavior of the variables considered in the simulation. These results make it possible to use a large amount of existing data from this crop to conduct modeling studies. The simulation errors were comparable to those found in other models and reported in the literature. The DSSAT/CANEGRO model estimates were better for the SP791011 variety. The yield forecast was less accurate for the RB835486 variety. The model reasonably simulated the sugarcane growth and development under the edaphoclimatic conditions of this Brazilian region.

\section{References}

Allen, R. G., Pereira, L. S., Raes, D., \& Smith, M. (1998). Crop evapotranspiration-Guidelines for computing crop water requirements. FAO irrigation and drainage paper 56 (300(9), D05109). FAO, Rome. 
Barros, A. C., Souza, J. L., Coelho, R. D., Barros, A. H. C., dos Santos Almeida, A. C., \& da Silva Junior, J. M. (2016). Parametrização do modelo DSSAT/CANEGRO para variedades de cana-de-açúcar em Alagoas. Revista Brasileira de Agricultura Irrigada, 10(3), 631-639. https://doi.org/10.7127/rbai.v10n300385

Berezuk, A. G., \& Neto, J. L. S. A. (2006). Eventos climáticos extremos no oeste paulista e norte do Paraná, nos anos de 1997, 1998 e 2001. Revista Brasileira de Climatologia, 2. https://doi.org/10.5380/abclima. v2i0.25370

CONAB (Companhia Nacional de Abastecimento). (2018). Acompanhamento da safra brasileira de cana-de-açúcar (v. 5, Safra 2018/19, n. 2, Segundo levantamento, pp. 1-86). Brasília, Brazil. Retrieved from https://file:///C:/Users/angel/Downloads/BoletimZCanaZ2ZLevantamentoZ18-19\%20(1).pdf

Dias, H. B., \& Sentelhas, P. C. (2017). Evaluation of three sugarcane simulation models and their ensemble for yield estimation in commercially managed fields. Field Crops Research, 213, 174-185. http://dx.doi.org/ 10.1016/j.fcr.2017.07.022

Dos Santos Vianna, M., \& Sentelhas, P. C. (2016). Performance of DSSAT CSM-CANEGRO under operational conditions and its use in determining the 'Saving irrigation'impact on sugarcane crop. Sugar Tech, 18(1), 75-86. https://doi.org/10.1007/s12355-015-0367-0

EMBRAPA. (2013). Sistema Brasileiro de Classificação de Solos (3rd ed.). Brsília, DF: Embrapa Solos.

Gómez-Aguilar, J. F. (2020). Multiple attractors and periodicity on the Vallis model for El Niño/La Niña-Southern oscillation model. Journal of Atmospheric and Solar-Terrestrial Physics, 197, 105172. https://doi.org/10.1016/j.jastp.2019.105172

Inman-Bamber, N. G. (1991). A growth model for sugar-cane based on a simple carbon balance and the CERES-Maize water balance. South African Journal of Plant and Soil, 8(2), 93-99. https://doi.org/ $10.1080 / 02571862.1991 .10634587$

Jones, C. A., Kiniry, J. R., \& Dyke, P. T. (1986). CERES-Maize: A simulation model of maize growth and development. Texas A\&M University Press, USA.

Jones, C. A., Wegener, M. K., Russel, J. S., Mcleod, I. M., \& Williams, J. R. (1988). AUSCANE-Simulation of Australian sugarcane with EPIC (pp. 160-194). Brisbane: Commonwealth Scientific and Industrial Research Organization.

Keating, B. A., Robertson, M. J., Muchow, R. C., \& Huth, N. I. (1999). Modelling sugarcane production systems I. Development and performance of the sugarcane module. Field Crops Research, 61(3), 253-271. https://doi.org/10.1016/S0378-4290(98)00167-1

Liu, D. L., \& Kingston, G. (1995). QCANE: A simulation model of sugarcane growth and sugar accumulation. Research and modelling approaches to assess sugarcane production opportunities and constrains (pp. 25-29). St. Lucia: University of Queensland.

Marin, F. R., Jones, J. W., Royce, F., Suguitani, C., Donzeli, J. L., Wander Filho, J. P., \& Nassif, D. S. (2011). Parameterization and evaluation of predictions of DSSAT/CANEGRO for Brazilian sugarcane. Agronomy Journal, 103(2), 304-315. https://doi.org/10.2134/agronj2010.0302

Marin, F. R., Thorburn, P. J., Nassif, D. S., \& Costa, L. G. (2015). Sugarcane model intercomparison: Structural differences and uncertainties under current and potential future climates. Environmental Modelling \& Software, 72, 372-386. https://doi.org/10.1016/j.envsoft.2015.02.019

Nassif, D. S. P., Marin, F. R., Pallone Filho, W. J., Resende, R. S., \& Pellegrino, G. Q. (2012). Parametrização e avaliação do modelo DSSAT/Canegro para variedades brasileiras de cana-de-açúcar. Pesquisa Agropecuária Brasileira, 47(3), 311-318. https://doi.org/10.1590/S0100-204X2012000300001

Raes, D., Steduto, P., Hsiao, T. C., \& Fereres, E. (2012). FAO, Land and Water Division, Rome, Italy.

Rossi, M. (2017). Mapa pedológico do Estado de São Paulo: Revisado e ampliado (No. 1, p. 118). São Paulo: Instituto Florestal.

Santa, L., \& Neto, A. (2015). Eventos climáticos extremos no Oeste Paulista e norte.

Santos, H. D., Jacomine, P. K. T., Anjos, L. D., Oliveira, V. A., Oliveira, J. B., Coelho, M. R., ... Oliveira, J. B. (2013). Brazilian system of soil classification. Revista ampliada (No. 3, p. 353). Brasília, DF: Embrapa.

Singels, A., \& Bezuidenhout, C. N. (2002). A new method of simulating dry matter partitioning in the Canegro sugarcane model. Field Crops Research, 78(2-3), 151-164. https://doi.org/10.1016/S0378-4290(02)00118-1 
Singels, A., Jones, M., \& van Den Berg, M. (2008). DSSAT v4.5-Canegro Sugarcane Plant Module. South African Sugarcane Researh Institute.

Soil Survey Staff, GNATSGO (Gridded National Soil Survey Geographic). (2019). Database for the Conterminous United States. United States Department of Agriculture, Natural Resources Conservation Service. Retrieved from https://nrcs.app.box.com/v/soils

Villegas, F. D., Daza, O. H., Jones, J. W., \& Royce, F. S. (2005). CASUPRO: An industry-driven sugarcane model. American Society of Agricultural and Biological Engineers (p. 1). 2005 ASAE Annual Meeting. https://doi.org/10.13031/2013.19062

Willmott, C. J., Rowe, C. M., \& Mintz, Y. (1985). Climatology of the terrestrial seasonal water cycle. Journal of Climatology, 5(6), 589-606. https://doi.org/10.1002/joc.3370050602

\section{Copyrights}

Copyright for this article is retained by the author(s), with first publication rights granted to the journal.

This is an open-access article distributed under the terms and conditions of the Creative Commons Attribution license (http://creativecommons.org/licenses/by/4.0/). 